\title{
Correction: Case of aggressive metastatic follicular variant papillary thyroid carcinoma with BRAF K601E and BCORL1 mutations
}

Attia D, Lurie A, Zhai Q, et al. Case of aggressive metastatic follicular variant papillary thyroid carcinoma with BRAF K601E and BCORL1 mutations. BMJ Case Rep CP 2020;13:e234208.

This article was previously published with an error in the authorship. Co-author 'Thomas Mesko' has been added as the 4th author in the revised version. The updated authorship is stated below:

Doaa Attia, Alexander Lurie, Qihui Zhai, Thomas Mesko, Robert Smallridge

(C) Author(s) (or their employer(s)) 2020. No commercial re-use. See rights and permissions. Published by BMJ.

BMJ Case Rep 2020;13:e234208corr1. doi:10.1136/bcr-2019-234208corr1

A) Check for updates

Copyright 2020 BMJ Publishing Group. All rights reserved. For permission to reuse any of this content visit https://www.bmj.com/company/products-services/rights-and-licensing/permissions/

BMJ Case Report Fellows may re-use this article for personal use and teaching without any further permission.

Become a Fellow of BMJ Case Reports today and you can:

- Submit as many cases as you like

- Enjoy fast sympathetic peer review and rapid publication of accepted articles

- Access all the published articles

- Re-use any of the published material for personal use and teaching without further permission

Customer Service

If you have any further queries about your subscription, please contact our customer services team on $+44(0)$ 2071111105 or via email at support@bmj.com.

Visit casereports.bmj.com for more articles like this and to become a Fellow 